\title{
Ancient Chinese philosophical advice: can it help us find happiness today?
}

\author{
Guoqing Zhang $\cdot$ Ruut Veenhoven
}

Published online: 28 February 2007

(C) Springer Science+Business Media B.V. 2007

\begin{abstract}
Confucianism, Buddhism and Taoism are three main classic Chinese philosophy schools, which all deal with the question of how one should live. In this paper, we first review these ancient recommendations and next consider whether they promise a happy life in present-day society. Recommended behaviours found in the ancient texts are compared with conditions for happiness as observed in presentday empirical investigations. Classic Confucianism appears to offer the most apt advice for finding happiness in present-day society, in particular because it recommends that one should be involved in real life. Classic Taoist advice is second best: its strong point is that it advises us against too much social conformism and bookishness. The advice given by classic Buddhists is better not followed in modern society.
\end{abstract}

Keywords Classic Chinese philosophy $\cdot$ Confucianism $\cdot$ Buddhism · Taoism $\cdot$ Life style $\cdot$ Happiness $\cdot$ Advice

\section{Introduction}

About 2,500 years ago, in the late period of the Chau (Zhon) dynasty, China was a typically agrarian society located along the banks of the Yellow River. In many respects, it could be compared to medieval Europe. Most people lived in the countryside in close-knit communities, the basic unit of society being the family: individuals belonged to their families, families belonged to their villages and villages belonged to members of a feudal warrior class, typically a vassal or a king.

G. Zhang $(\bowtie)$

Department of Philosophy, Zhejiang University, Hangzhou 310028, China

e-mail: zgqing2002@msn.com

R. Veenhoven

Department of Sociology, Erasmus University Rotterdam, P.O. Box 1738, 3000 Rotterdam, The Netherlands e-mail: veenhoven@fsw.eur.nl 
Philosophers earned their living primarily at noble courts, where they advised rulers and educated their descendants. Their advice for a good life was mainly tailored to the conditions of the nobility.

There were several philosophy schools around this time with Confucianism and Taoism pre-eminent among them. A third major school appeared 500 years later, when Buddhism was imported from India. These three classic philosophies provide different views on life and differ in the advice they give as to how to live a good life. None of the schools differentiate between living a 'good' life and living a 'happy' life.

These classic teachings are commonly seen as eternal wisdom and assumed to be still applicable today. Are they? Some of the advice may be wiser than some of the other advice; and the many contradictions suggest that some may even be false. Also some of the admonitions may be more apt in present-day modern society than others and some may not be applicable at all today, the advice having been tailored to conditions in the past.

In this paper, we consider how apt this classic advice is for finding happiness in our day. To that end we will first briefly review the three classic philosophies, focussing on advice for leading a good life. Next, we compare this advice with findings on concomitants of happiness in modern society, and check whether recommended behaviours tend to go with greater happiness. For that purpose we draw on research results gathered in the World Database of Happiness (WDH) (Veenhoven, 2005).

In this way, we assess the worth of these ancient teachings as a guide to a satisfying life in modern society. We do not evaluate their wider merits, such as their moral quality or objective truth. Our aim is to help people make more informed choices in their life by making these sources of information more readily available.

\section{Three ancient teachings on leading a good life}

In the review below, we draw on the earliest writings of followers of these three traditions. The interested reader can find more detail in Lin (1949), Chan (1969) and Fung (1985).

\subsection{Confucianism}

\subsubsection{Origin}

Confucianism originated about 600 years before the Christian era in the east of present-day China (Shangdong province). Its founder, Confucius (551-472 B.C.), came from the landed classes. He wrote two books: The Great Learning and The Doctrine of the Mean. There are two other seminal works of Confucianism, the Confucian Analects edited by his disciples and the Works of Mencius written by Mencius (372-289 B.C.), an important contributor to Confucianism. These "Four Books" deal with a number of subjects, such as politics, ethics, law and education; one of the main topics is how to live a good life. 


\subsubsection{View on life}

The pivotal idea of Confucianism is 'Jen'. In the simplest sense, 'Jen' means a feeling of compassion, i.e. concern for the well being of others. Confucius said, 'Jen' means "to love fellow-men", and "where there is 'Jen', there is man". 'Jen' is the essence of man, and it is almost equal to 'virtue'. If someone has 'Jen', it is implied that he has 'virtue', and if someone has 'virtue', it is implied that he has reached the conditions required to live a good life. Followers of Confucianism must bring Jen into their own society, into their social relations. Every activity should be carried out in accordance with virtues such as benevolence, duty, property, intuition and trust, and every man can live up to the virtues and thus live a good life. Confucius said: "Is benevolence so far away? If I want benevolence, then benevolence is here!' The quality of your life rests in your own hands.

\subsubsection{Advice for a good life}

To live a good life one should live up to the virtues. Confucius describes the following ones: "There are learning extensively, and having a firm and sincere aim; inquiring with earnestness, and reflecting with self-application: virtue is in such a course" (Legge, 1971, p173). So, a positive attitude towards learning is central to virtue, the more knowledge one has, the closer to virtue one gets. Learning should be a part of every place and every thing. Learning is the first necessary condition of a good life. As Confucius said,

"There is the love of being benevolent without the love of learning-the beclouding here leads to a foolish simplicity. There is the love of knowing without the love of learning - the beclouding here leads to dissipation of mind. There is the love of being sincere without the love of learning - the beclouding here leads to an injurious disregard of consequences. There is the love of straightforwardness without the love of learning-the beclouding here leads to rudeness. There is the love of boldness without the love of learning - the beclouding here leads to insubordination. There is the love of firmness without the love of learning - the beclouding here lead to extravagant conduct" (Legge, 1947, p156).

So the more a person learns, the more he has a good life.

Confucius enumerated more virtues in The Great Learning: to investigate things, to keep your thoughts sincere, to rectify your heart, to cultivate yourself, to regulate your family and your village, to govern your state rightly, and to make the whole kingdom tranquil and happy. In his view a people's quality of life bears close relation to the quality of their government. Confucianism promotes benevolence on behalf of the ruler. A ruler's good name and good life comes from the quality of life of the ruled. Confucius said:

"At fifteen, I had my mind bent on learning, at thirty, I stood firm. At forty, I had no doubts. At fifty, I knew the decrees of Heaven. At sixty, my ear was an obedient organ for the reception of truth. At seventy, I could follow what my heart desired, without transgressing what was right"' (Legge, 1947, p8). 
Confucianism accepts society and advises its followers to engage in it, a life of active involvement is deemed better than passive distance. Positive action and thinking things over, is seen to enable the individual to lead a good life.

So, for Confucianism, knowledge, learning, responsibility, duty are important values. Social values are also important, in particular friendship and family. The same is true for tolerance, dialogue, new ideas and thoughts: it is also important to give up older ideas. A man should reflect upon himself every day. Reflection is important: it is the precondition for improvement of oneself.

When we lead a simple, normal and rational life, then we can have a good life (Guoqing, 2001b, p3). Life is worthwhile and we should be careful to preserve it and live long. Death is to be ignored, and also life after death. Confucianism recommends that people deal with reality 'here and now', and not to dwell on illusory troubles (Guoqing, 2001a, p82). Yet when death is imminent they should accept it.

Confucianism underlines the importance of the rule of law, of government and communities; these social environments are of central importance for the good life of the people. For Confucianism, the ideal society stresses merit and virtue. Morality is a main requirement for a good life, not only for individuals but also for community as a whole. The humanities, arts, sciences and technology can also help us to reach a good life, but morality is more important. Confucianism does not embrace the idea of democracy: it advocates meritocracy; society should be ruled by wise men with virtues but not by the people.

\subsection{Taoism}

\subsubsection{Origin}

Taoism, another important philosophy of ancient China, was also founded in the sixth century B.C. The Chinese philosopher Lao Tzu was a slightly older contemporary of Confucius. His main work was the Tao Te Ching (Dao De Jing). Zhwangtze was another important Taoist philosopher who wrote Chuang-tzu.

\subsubsection{View on life}

In his History of Chinese Political Thought: During the Early Tsin Period, Liang Chichao observed that the fundamental difference between Taoistic and Confucian philosophies is that Confucian thinking centers around men, and Taoists thinking around nature (Chichao, 2000, p73). Taoism and Confucianism have to be seen as two distinct responses to the social, political and philosophical conditions of life in that era. Whereas Confucianism is greatly concerned with social relations, conduct and human society, Taoism has a much more individualistic and mystical character. Confucians believed that humans can realize their own ends, through their own ability, power and effort, while Taoists believed that the laws of nature are all-powerful. 'Tao' existed before man and is eternal and un-changeable. For Taoism, people should keep the balances between human beings and Nature, between individuals and society, between oneself and others. Everybody has an identity and independence, an own individuality, dignity and freedom. People should not change the natural order, called Tao, but should follow it. Taoism asked people to take care of the natural world, to become a part of nature. Their bodies and their hearts should belong to nature. 
Taoism holds that life is limited and temporary and that it is impossible for people to understand the truth of the world and that of human beings themselves. Knowledge always limits the view of people, alienates from the truth of the world and violates the Tao. So the best way to have a good life is to follow the 'Tao', the 'Law' of nature. This will make people happy. Tao is everywhere. So Laotze said:

"There is a being that is all-inclusive, existing before heaven and earth. Calm indeed, and incorporeal, it is alone and changeless. Everywhere it functions unhindered and may be considered the mother of all creation. I do not know its name, but I characterized it as "Tao", (Laotze, Tao The Ching).

\subsubsection{Advice for a good life}

In comparison to nature and Tao, man is weak and insignificant. In Zhwangtze's words, "A man in the universe is like a pebble or a twig in the mountains. As such he can only obey nature. He may be useful in a small way, but it is beyond him to originate anything"'(Zhwangtze, Autumn Water).

Life is useless for every other thing but itself; man is useless to others and himself. Taoism asks people not to be concerned about matters of birth and death. It is better to forget the truth of the real conditions of life, and the truth of the human condition. No knowledge, no worries, nothing to wait for, nothing to be worried about. This is the natural condition of happiness. It is not necessary to be perfect or complete, "Great perfection seems incomplete, but does not decay. Great abundance seems empty, but does not fail. Great truth seems contradictory; great cleverness seems stupid; great eloquence seems awkward"(Laotze, Tao The Ching). But no social condition could limit our efforts to be happy, we can lose anything in society, but still be happy.

Taoism distinguishes two levels of life, one is the natural level or inner life, and the other is the social level or public life. "Live peacefully and delight in your own society, dwell within cock-crow of your neighbors, but maintain your independence from them"(Laotze, Tao The Ching). Taoism pays more attention to private life than to societal life, where people's life is near to nature and far from communities. Under the conditions of nature and privacy, Taoism focuses on the art of personal living, but not on the art of social life. Taoism advises people to avoid involvement in public life. As Laotze said,

"Health or reputation: which is held dearer? Health or possessions: which has more worth? Profit or loss: which is more troublesome? Great love incurs great expense, and great riches incur great fear. But contentment comes at no cost. Who knows when to stop does not continue into danger and so may endure long" (Laotze, Tao The Ching).

The more you give up outside matters, the more you gain inner peace. When you gain the meaning of life, you give up the words of life. When you realize the truth of the world, you have no longer to worry about your limited and temporary life. Tao rules everything. When you have Tao, you will be a truly happy person.

As can be seen, Taoism and Confucianism have different perspectives on what makes for a good life. Confucianism stresses learning, but for Taoism the fundamental condition is Tao. Tao means nothing, in reality: we cannot find Tao; the more we want to capture Tao, the more we depart from it. We cannot find the real 
conditions of a good life in the outside world; we can only derive them from our inner world, from our spiritual condition. LaoTze says: "An excess of colour blinds the eyes; an excess of noise ruins the ear; an excess of condiments deadens the taste". So if a person wants to keep his mind peaceful and calm, it is better he avoids situations that might stimulate him. LaoTze states, "If one does not see desirable things one's mind would not be disturbed". So people have to resist seduction, temptation and interferences from the social and political world. In this Taoism is against civilization and against modern technology. LaoTze says,

"When sainthood is abandoned and the learned are outcaste, robbery will cease; when jades are thrown away and jewels destroyed, pilfering will not occur; when mementoes are burned and seats broken, the people will become simple and honest. When the bushel is smashed and the scale bent, the people will have no quarrels" (Laotze, Opening Trunck. Cited from Chichao, 2000, p78).

A simple life is the best life. Taoism argues against the development of wisdom in people. For Taoism, children are the happiest and most healthy human beings.

Taoism also differs from Confucianism with respect to the kindness of the ruler. As Laotze said, "Manage a great nation as you would cook a delicate fish. To govern men in accord with nature, it is best to be restrained". And: "when government is lazy and informal, the people are kind and honest, when government is efficient and severe, the people are discontented and deceitful" (Laotze, Tao The Ching). For Taoism, rulers should do nothing for their people. If rulers "take no action, and the people nurture each other; make no laws, and the people deal fairly with each other. Own no interest, and the people cooperate with each other. Express no desire, and the people harmonize with each other'(Laotze, Tao The Ching). Taoist philosophy prefers the conditions of anarchism, asceticism, individualism and naturalism. The arguments run against collectivism and make a plea for individualism. "We are each unique, and therefore valuable. Although the sage wears coarse clothes, his heart is jade" (Laotze, Tao The Ching). The rule of law is not necessary for government. "Do not control the people with laws, nor violence nor espionage, but conquer them with inaction" (Laotze, Tao The Ching). The laws of nature, the Tao, are supposed to be sufficient for people. Nothing else is needed to live a good life.

So, according to Taoism, things are said to create "unnatural" action (wei) by shaping desires $(y u)$. The process of learning the names (ming) used in the doctrines helps one to make distinctions between good and evil, beautiful and ugly, high and low, and "being" $(y u)$ and "non-being" $(w u)$, thereby shaping desires. To abandon knowledge is to abandon names, distinctions, tastes and desires, and thus spontaneous behaviour (wu-wei) will result.

For Taoism the most important matter is individual freedom.

"The more morals and taboos there are, the more cruelty afflicts people. The more guns and knives there are, the more factions divide people. The more arts and skills there are, the more change obsoletes people. The more laws and taxes there are, the more theft corrupts people" (Laotze, Tao The Ching).

People are advised to follow the laws of nature and to avoid societal norms: people should wait for nothing, should desire nothing. When you give up all things, you have something left, that is happiness. 
Taoism is not a tolerant philosophy. It stresses freedom, but this freedom does not include the freedom of choice. Knowledge, learning, responsibility, duty and other social values are considered unimportant. The same is true for friendship, family and other social ties. Taoism lacks tolerance and dialogue. Difference is not allowed, the philosophy stresses the importance of discipline. New ideas and thoughts are to be limited.

Taoism agrees with Confucianism on the importance of reflection. Both philosophies want people to care about their real lives. But Taoism takes a very different route to achieve this aim: it does not stress the importance of the rule of law, of government and communities. The social environments of people are not considered important for the happiness of people. Taoism only cares about the natural condition of a good life. The ideal society is a native society. Morality is considered to be the distortion of peoples' natural and native life, and will only decrease happiness. Taoism lacks the idea of democracy. It argues against knowledge, science and technology, these are seen not as the means to enhance the quality of life, but as obstacles to a good life.

In a nutshell: Taoism is a negative philosophy of social life, but a positive philosophy of natural life. Confucianism states that happiness is possible if you embrace life, learn and put in a lot of effort. Taoism is more pessimistic: happiness is possible, but only if you are wise enough to realize that you can do little about it. The good life can be reached if you cease to try to make things better for yourself.

\subsection{Buddhism}

\subsubsection{Origin}

Buddhism originated in Northern India about six hundred years before the Christian era. Its founder was Buddha Gautama (560-480 B.C.), also known as Shakyamuni "the sage from the tribe of the Shakyas". The historical Buddha was an Indian prince, who left palace and family to gain spiritual enlightenment. Buddhism was introduced into China around the time Christ was born, having travelled along the silk-road, and later to some extent, into Southeast Asia. After a few centuries of assimilation, Buddhism evolved into many sects in the Sui and Tang Dynasties and became localized. During this process the indigenous cultures of Confucianism and Taoism were blended with Buddhism. Chinese Buddhism has had a great influence on traditional Chinese ideology and art.

\subsubsection{View on life}

Buddhism teaches that all phenomena are impermanent and interdependent; the world is continually in flux, coming into existence and passing away, conditioned from one moment to the next by interrelated phenomena. Buddhism focuses on suffering because only by understanding a problem can a solution be found. The more we adhere to a belief in a self, the more pain we feel. All of the Buddha's teachings are a means to experiencing liberation from a self-centred existence in which suffering is inevitable.

Buddhism has Four Noble Truths: (1) All life is characterized by suffering, (2) Suffering originates from craving, (3) The complete stopping of craving can stop suffering, (4) Finally the fourth truth consists of the steps that must be followed 
along the Noble Eight-Fold Path to stop suffering: right views, right intentions, right speech, right conduct, right livelihood, right effort, right mindfulness and right concentration. The end result is attainment of Nirvana, a state of saintliness, that is characterized by perfect inner peace, enlightenment and the abolition of all wants.

For Buddhism, the world as we see it is an illusion, which conceals the true reality beyond. All the phenomena of the universe perceived by an individual sentient being are manifestations of the mind. Whenever an individual acts, speaks, or even thinks, the mind of that individual is doing something and that something will produce results, no matter how far in the future. Therefore, the existence of an individual is made up of a chain of causes and effects.

There are three basic concepts in Buddhism, Karma: the force behind the chain of causes and effects. Karma is the assumption that the status into which one is reborn after any death is determined almost automatically by an accurate balancing of merits and demerits accumulated as a result of good or bad deeds during previous lives. Samsara: the wheel of birth and death. Living creatures experience many lifetimes. After each death, they are reborn into another state. Nirvana: the state of saintliness. This is the state where one has broken free from the wheel of birth and death. Having reached Nirvana you can die and do not have to be reborn, thus you escape from the suffering that is the essence of living. Classic Chinese Buddhism is a religion, an ideology, a philosophy and a way of life.

\subsubsection{Advice for a good life}

Classic Chinese Buddhism expects people to look for happiness in their own hearts; they should give up all outside relationships. Relationships bind and limit the individual. Buddhism recommends people to turn their attention to their personal, inner worlds, and to give up every illusory desire of happiness. Instead they should focus on the spiritual enlightenment. No actions, no movements, but mediation. For this kind of unworldly Buddhism, everything is the same and everything is nothing. So doing something is the same as doing nothing. The difference is not important. Knowledge is also not important. Friendship is nothing, nor is family. Yet Buddhism still asks people to be tolerant and kind, to bear the pain and sorrow in the world. The Buddhist has to give up every thing, including one's own happiness.

For classic Chinese Buddhism, there is not much value in knowledge, learning, responsibility, duty, nor in friendship, family or other social ties. Tolerance is important, conversation is important, difference is also important. Meditation and self-consciousness is the first condition for a good life. Individuals should reflect upon themselves every day. Reflection is the precondition for improvement of oneself. People need not hope for a long life, they should always care about death and life after death.

Thus Buddhism does not stress the importance of the rule of law, the government and communities, nor does it stress the importance of the humanities and arts, and it argues against science and technology as a means of improving life. Knowledge is not a necessary condition of a good life. Buddhism also lacks the idea of democracy. In short, this Buddhism is another negative philosophy of life, and is even more negative than classic Taoism. Taoism allows for the possibility of having a happy life following the rules of nature, but for ancient Buddhism the ultimate goal is to escape from the cycle of death and re-birth. 
There is much variation in Buddhism and the above description of early Chinese Buddhism does not fit all of it.

\subsection{Philosophies compared}

The three ancient Chinese schools of philosophy hold very different views of life. The advice they give for a good life differs accordingly. This holds true for almost all aspects of life, such as social success, intimate ties and morals. An overview of the differences and similarities between the three philosophies regarding advice for a good life is given in Table 1.

Table 1 Views on the good life in three ancient Chinese philosophies

\begin{tabular}{|c|c|c|c|}
\hline \multirow[t]{2}{*}{ Objects of advice } & \multicolumn{3}{|c|}{ Philosophy schools } \\
\hline & Confucianism & Taoism & Buddhism \\
\hline \multicolumn{4}{|l|}{ Life } \\
\hline Life itself & \pm & ++ & _- \\
\hline Long life & + & ++ & + \\
\hline Death & \pm & - & + \\
\hline Life after death & - & + & ++ \\
\hline \multicolumn{4}{|l|}{ Quality of life } \\
\hline Happiness & + & ++ & \pm \\
\hline Health & + & ++ & - \\
\hline \multicolumn{4}{|l|}{ Career } \\
\hline Occupation & + & + & - \\
\hline Income, wealth & + & - & -- \\
\hline \multicolumn{4}{|l|}{ Social ties } \\
\hline Friendship & + & - & - \\
\hline Family & ++ & + & - \\
\hline Marriage & ++ & \pm & - \\
\hline Community & ++ & \pm & \pm \\
\hline \multicolumn{4}{|l|}{ Society } \\
\hline Morality & ++ & \pm & - \\
\hline Government & ++ & - & - \\
\hline Rule of law & + & \pm & \pm \\
\hline \multicolumn{4}{|l|}{ Means } \\
\hline Rationality & + & - & - \\
\hline Humanities and arts & ++ & + & + \\
\hline Technology & + & - & - \\
\hline Knowledge & ++ & + & - \\
\hline \multicolumn{4}{|l|}{ Values } \\
\hline Responsibility & ++ & \pm & + \\
\hline Duty & ++ & + & + \\
\hline Freedom & + & \pm & -- \\
\hline Tolerance & + & -- & ++ \\
\hline
\end{tabular}

$++=$ Very positive

$+=$ Positive

$\pm=$ Ambivalent

$-=$ Negative

$--=$ Very negative 


\section{Help for a happy life in modern society}

Each of the three philosophies may have been conducive to a happy life for the people addressed originally: the apparent appeal of these ideas at least suggests this. Yet this does not guarantee that this wisdom is equally relevant for the average citizen in modern society. Although there may be universal truth in some of the admonitions, some of the advice may also be counterproductive in the present day context.

Below we explore the actuality of the recommendations using related findings drawn from recent empirical research on conditions for happiness. We examine whether the recommended behaviours tend to go together with greater enjoyment of life. We do this at two levels. First, at the level of the individual, i.e. whether persons who follow the counsel provided above are more likely to be happy than individuals who do not. Then, at the societal level, we assess whether average happiness is higher in nations where ideas drawn from the three classic Chinese philosophies are generally endorsed. This latter test is particularly relevant for Confucianist advice, since this canon aims at the personal happiness of its elitist audience and at the well being of the people they rule.

We can draw on a large body of empirical research on happiness in present day nations all over the world. Most of these findings are gathered in the World Database of Happiness (WDH), which is a collection of research findings on subjective enjoyment of life that can be browsed on the web (http://worlddatabaseofhappiness.eur.nl) (Veenhoven, 2005). Since research in this field is abundant, we cannot cite all the studies we use separately. Instead, we will note the section in the WDH where these data can be found, in particular the relevant section of the WDH's "Correlational Findings". These sections are indicated using codes, for instance "E 1" for findings on happiness and education.

These data concern "happiness" in the sense of "subjective enjoyment of one's life-as-a-whole", in other words "life-satisfaction" as defined by Veenhoven (1984, Chap. 2). This concept differs from notions in Chinese philosophy that have also been denoted by the term happiness. For instance, life-satisfaction is not the same as finding eternal peace in Nirvana. So this paper does not test whether the advice of a philosophy fits its own notion of the good life (called "happiness"), but how it works out on happiness as life-satisfaction.

Below we follow the themes in scheme 1 and consider recommendations on different aspects of life. In each case we summarize the position of the three philosophies and then inspect the correspondence with research findings on conditions for happiness.

\subsection{Value life?}

Above we have seen that the classic Chinese philosophies differ in how they value earthly life. With respect to private life, Taoism is the most positive and Buddhism the most negative. With respect to public life, Confucianism is the most positive and Buddhism still the most negative. What attitude is most conducive to a happy life? The available research findings provide some clues, but no definite answer.

A study among American students (Fordyce, 1972) found the subjects who endorse a positive view on life tend to be happier than pessimists. This could mean 
that a positive view on life adds to happiness, but causality could also work the other way. As yet only one study has separated these effects. Goodhart (1985) followed students over time and found that the ones who dealt with recent stresses positively increased most in happiness 2 months later.

Fordyce further found that students who valued 'meditation on inner life' and 'salvation', tended to be less happy, which suggests that we are happier when we are involved in real life. This interpretation is confirmed by studies on happiness and personality: happy people are typically more active ( $\mathrm{P} 4.3$ ), ambitious ( $\mathrm{P} 4.2$ ), extraverted (P 4.39) and zestful (P 4.120). Resignation is typically associated with unhappiness ( $\mathrm{P}$ 4.98).

At the societal level these are also indications that a positive view of earthly life makes life more enjoyable. Average happiness tends to be higher in nations where human life is most respected, for instance higher in nations that provide strong legal protection ( $\mathrm{N}$ 4.9.2) and where the number of fatal accidents is low (N 7.2).

Does valuing of longevity also add to happiness? As yet no investigation has examined precisely this relationship, but below we will see that care for one's health goes with happiness. People who try to keep in good shape will probably do so because they want to have long and healthy lives. The Buddhists' advice to prepare for death is unlikely to add to the enjoyment of life, since thinking often about death appears to be most common among the unhappy (Bradburn, 1969, p154). This evidence fits best with the Taoist position and least with Buddhist guidance.

\subsection{Enjoy life?}

Classic Taoism recommends plucking the pleasures of life. It does not advise people to pursue goals in the long run, because they have to realize that fate is not in their hands. Taoism advises people to enjoy the moment and advises against the pursuit of long term rewards in an academic career or public life. Confucianists recommend at least moderate enjoyment. Confucianism is more positive about the possibilities to make something of your life than is Taoism, but people always have to put effort into it and maybe they forget to enjoy the present moment, because they always have to have an open eye for the future and for different areas. Classic Buddhism warns against the pursuit of happiness, since this will only lead to disappointment and diverts us from spiritual purification. A similar admonition is promulgated by ascetic variants of Christianity. What guidance applies best for the average person these days?

A first indication comes from research on the relationship between values and happiness. Ethical rejection of happiness does not go with a higher level of happiness. Fordyce's (1972) study showed greater happiness among American students who endorsed the pursuit of personal 'enjoyment of life' and saw 'cheerfulness' as an important instrumental value.

A second indication is that actual pleasure-seeking works positively towards happiness. Several studies show greater happiness among people who frequently engage in pleasurable activities, such as holidays, going out and drinking wine. Elsewhere these findings are reviewed in more detail (Veenhoven, 2003). Although it is often said that such a hedonic life-style adds only to short-lived happiness, there is no evidence for long-term harm. Follow-up studies to date have shown no hangover effect. 
This brings us to the third piece of evidence. The best predictor of current happiness appears to be earlier happiness, even happiness measured more than 10 years ago ( $\mathrm{H} \mathrm{5.2}$ ). This suggests that happiness is a self-reinforcing state. Rejecting happiness is thus not a good way to get happy, at least not in conditions where happiness is obtainable.

There are also clues at the societal level. Average happiness tends to be higher in nations where hedonic values are most endorsed ( $\mathrm{N}$ 4.10.2) and at this level there are also indications of self-reinforcing effects: happiness seems to foster several societal conditions for happiness such as democracy and tolerance. Again, the data support Taoist and Confucianist advice, but not Buddhist guidance.

\subsection{Live healthily?}

Taoism recommends that we take care of our bodies and live healthily. Some writings in this tradition even see mystical value in the cultivation of the body. Confucianism also advises a healthy lifestyle and the avoidance of physical risks. Yet ancient Chinese Buddhism sees little value in the flesh and recommends physical privation for inner purification. Which of these recommendations is best followed for living a happy life?

A healthy life-style seems to be conducive to happiness. People who pay attention to their health tend to be happier. This appears to be in positive correlation with controlling one's weight and acting on symptoms of disease (H 8). There are indications that healthy nutrition goes with higher happiness $(\mathrm{N} 8)$ and there is a positive correlation between taking part in sporting activities and happiness (S 12). Again, mere correlation does not provide hard proof, since happiness could also enhance healthy living. Yet it is at least plausible that healthy living affects happiness through its effect on health.

Not surprisingly, people who are in good health appear to be happier than people in poor health. The causation is reciprocal, happiness adds to good health, but good health also adds to happiness (P 6.1.1). So there is a point in caring for one's health. Although it is true that we will all die, this care for one's health promises a happier lifetime and also a longer one.

At the societal level there is also evidence that concern for health adds to happiness: the greater the share of the national income invested in health care, the happier citizens are on an average Not surprisingly there are also strong correlations with health-outcomes; average happiness is higher in nations where people feel most healthy and live longest (Kircaldy, Furnham, \& Veenhoven, 2005). Once more Taoist and Confucian advice appears to be more conducive to happiness than Buddhist counsel.

\subsection{Be successful?}

Classic Confucianism recommends devotion to one's occupation and is positive about wealth earned by working. Taoism is also positive about professionalism, but less so about a person's resultant earnings. Classical Buddhism is again negative about both. What stance is most conducive to happiness now?

There are many studies on the relationship between happiness and employment. These studies show that the employed are typically happier than the unemployed 
and that this difference is at least partly due to an effect of employment on happiness (E 2). This effect is most pronounced among male breadwinners. Gainful employment is mostly unrelated to happiness among married women; and retirement does not reduce happiness ( $\mathrm{R} 3$ ). This pattern is not reproduced at the societal level. Average happiness is higher in nations where a great part of the population is economically inactive (N4.3.4), which could mean that work is not equally beneficial for everyone.

There are even more studies on happiness and income. These studies also show positive correlation, in particular in poor countries. Part of this correlation is due to a causal effect of income on happiness (I 1). Likewise, research has shown modest positive correlation between happiness and material possessions, but causality has not yet been established in this case (P 10).

Similar relationships have been observed at the societal level. Average happiness is clearly higher in the economically most prosperous nations. This relationship appears to be subject to the law of diminishing returns, but there is no evidence that countries can be too prosperous.

All in all, this evidence is most in line with the Confucianist position.

\subsection{Invest in intimate ties?}

Confucianism advises us to invest in social relationships, in particular in filial ties. Taoism also recommends us to take care of our social ties, but warns against becoming too involved. Classic Buddhism advises against close connection with other people: since man is bad, it is better for the individual to care for their soul. Which wisdom is wisest?

Many studies have shown that people with strong social networks are typically happier than people without such connections. This appears most clearly in the numerous studies about marital status and happiness. The married are happier than singles, more so than never-married singles and once married people, i.e. divorced and widowed people (M 2). Likewise, there is good evidence that people with many friends are happier than people with few friends, in particular if a person has a confidant among their friends (F 6). The same is true for bonds with relatives (F 3).

Again these statistical relationships could be due to the effect of happiness on intimate bonds rather than the converse. In the case of marriage it has been shown that both effects are involved: though happy people have a better chance of finding a spouse, it is also clear that marriage adds to happiness (M 1). Recently this has been powerfully demonstrated in a large-scale follow-up over 12 years (Stutzer \& Frey, 2003).

These findings are corroborated in observed correlations with personality traits: sociability being typical for happy people. The happy tend to score low on aggressiveness ( $\mathrm{P} 4.1)$ and irritability (P4.62), and high on extraversion ( $\mathrm{P} 4.39)$, cooperativeness ( $\mathrm{P} 4.107)$, kindness ( $\mathrm{P} 4.64)$ and trust $(\mathrm{P} 4.115)$. Yet this line of research also suggests that autonomy is conducive to happiness, since the happy tend to score high on independence (P 4.54), inner control ( $\mathrm{P} 4.58)$ and self-confidence (P 4.100) and low on guilt ( $\mathrm{P}$ 4.47).

A similar effect has been observed at the collective level: there is a strong positive relationship between density of friendships in a country and average happiness, and a slight negative correlation between divorce rate and happiness ( $\mathrm{N} 4.11$ ). 
In an evolutionary perspective it is quite logical that bonds with family and friends add to happiness. Close relationships were crucial for survival in hunter-gatherer society and hence selection has probably worked against a preference for living alone. Yet, it is also understandable that there are limits to this need for intimacy, since adaptation also requires some relational flexibility and independence. Together these opposite tendencies fit the theory that humans flourish better with changeable "weak" ties than with lifetime "strong" ties (Maryanski \& Turner, 1992). In line with this theory, people appear to live happier lives in individualistic societies than in collectivist ones (Veenhoven, 1999).

Seen in this light, Taoistic advice seems to fit better with human nature than Confucianist recommendations. The Buddhist's counsel to forego any intimate involvement is clearly not at all in line with human nature.

\subsection{Engage in society?}

Confucianism advises the individual to be involved in society, while Taoism recommends that one should retreat to nature, and Buddhism advocates withdrawal from all earthly commitments. Which advice is most conducive to a happy life for today's average citizen?

At the individual level, many studies have found that people who are involved with society are typically happier than people who are not. First, this is apparent in the relationship between employment and happiness; people with a paid job are happier than the unemployed. This relationship is at least partly due to an effect of employment on happiness (E 2). Second, there is ample evidence for a positive effect of participation in civil organizations. Members of churches, clubs and political parties are happier on average than non-members. Likewise, active participants tend to be happier than passive members. In this case, cause and effect have not yet been separated, so the relationship could be entirely due to a greater drive to participate on behalf of the happy (S 7). Likewise, studies on political behaviour show that the happy are more concerned about political issues; they follow the news more closely and vote more often ( $\mathrm{P} 8$ ). This inclination is also reflected in values, for instance 'justice' is more valued by the happy (V 2). Yet again we are in the dark about the direction of causality.

Similar relationships are observed at the societal level. Average happiness tends to be higher in 'civil societies', that is, in nations where many citizens participate actively in public decision-making and where a dense network of political parties, interest groups and voluntary associations facilitates voice and involvement (N 6.4).

All this supports the Confucianist view. Although Confucianism prefers meritocracy to democracy it does encourage political involvement.

Still a Taoistic retreat to nature might be equally satisfying. Is it? Research is less abundant on this topic. To date there has only been one empirical study on the happiness of urban people who have moved 'back to the land'. These people appeared to be quite happy, and the more so when they had managed to achieve a way of living that matched their ideal life style (Brinkerhoff, 1986). Unfortunately this study did not establish whether these idealists are happier than comparable people in a town, or whether they become happier after the move to the country than they were before their move. It could also be a personality factor. Some people 
are happier outside a city, for others it is the other way around. Ergo: the result could be due to selection.

An indication of whether life is more satisfying on the land can be found in the many studies that compared average happiness in urban and rural settings. Findings diverge between developed and under-developed nations. In developed nations there is hardly a difference in happiness: people are fairly happy in both cities and the country. This is possible due to the fact that modern culture has penetrated deeply into the country in developed societies. People are clearly less happy in under-developed nations and rural people tend to be much less happy than city dwellers in these countries ( $\mathrm{L} \mathrm{10.2)}$. This issue is discussed in more detail in Veenhoven (1994).

These findings suggest that people thrive well in modern society and hence we should think again before we follow Taoistic advice to turn away from civilization.

\subsection{Meet your obligations?}

A sense of duty is central to classic Confucianism, in particular one's obligations to kin. A major strand of Confucianist advice revolves around acting responsibly and fulfilling one's duties. This creed was quite functional in the context of an agrarian society, which depended very much on the solidarity of the clan. Yet, the same conditions have also given rise to reactions against the grain. Taoism is mixed about this moral pressure and Buddhism rejects it altogether. Which way is most suitable in present day society?

Empirical indications are scarce for the individual level. The above-mentioned study among American students found that adherence to "social values" was more common among the happiest than among the least happy. Happy students also appeared to be more concerned with fairness and justice. Another study among air-force personnel found somewhat more support for the "Protestant" work ethic among the happy. The difference is small however and could be an effect of happiness on moral conviction rather than the reverse (V 2).

Some studies on personality have given similar indications. The happy score higher on tests of conscientiousness ( $\mathrm{P} 4.16)$ and are rated as more moral ( $\mathrm{P} 4.70)$, persistent (P 4.81), self-controlled (P 4.53) and trustworthy (P 4.116). Yet the happy tend to be less conformist, while above we have seen that the happy are more independent (P 4.54) and less inclined to feel guilty (P 4.47).

At the national level we see a negative effect. Average happiness is clearly lower in collectivist societies than in individualistic ones and an emphasis on duty is most characteristic of collectivist culture. Probably this is because heavy social obligations interfere too much with personal self-actualisation (Veenhoven, 1999).

These data do not tell us what is the optimal amount of duty; still they do indicate that more is not always better. As such they can be seen to support the Taoist position.

\subsection{School yourself?}

Confucianism venerates intellectual perfection and therefore strongly stresses education. A good life is that of a literate individual. Taoism is also positive about education, in particular about education in the humanities. Yet Taoism warns 
against unnatural studiousness and is critical of rationality and technology. Classic Buddhism rejects intellectual education altogether, advising the individual to seek out mystic experiences. Which piece of advice is most likely to result in a happy life today?

There is a lot of research on education and happiness at the individual level. Most studies find that well-educated people are typically happier than people with a lower level of education. This difference is greater in countries where the average level of education is low, than countries where the average level of education is high. Some studies in the latter countries have even observed a slight negative effect, university graduates being somewhat less happy than middle level educated compatriots. The correlations are considerably abated when controlled for income and occupational status, suggesting that the relationship is partly due to the extrinsic advantages of a good education and only partly to the intrinsic reward of knowledge (E 1.2).

Still it could be that the correlation is largely due to greater studiousness on behalf of the happy rather than to effects of education on happiness. The available follow-up studies suggest this is indeed the case. Early education does not predict later growth in happiness, while early happiness does predict a later level of education (E 1.1). Of particular interest in this context is a follow-up study among gifted women in the USA from 1921 to 1972 . Around age 12 these women scored 135 or higher on an intelligence test, so they are most likely to have benefited from education. Yet at age 62, college graduates appeared to be little happier than women with some college education or those who had stopped at a high-school education (Sears \& Barbee, 1977, pp40-64).

There are more indications that school education does not add much to happiness. One is that happiness appears to be unrelated to IQ (I 3). Another clue is that students are not happier than their working age-mates (S 1.2.1), nor are they any happier than the general population (O 1.2). Lastly, a 'theoretical' value orientation appeared to be negatively related to happiness among American university students (V2.1).

All this suggests that learning more than average does not really add to one's happiness in present day intellectual society. Although there are evident rewards in higher education, these advantages are apparently balanced by less evident disadvantages.

Although it does not really matter whether one is oneself very well educated, it does matter whether one lives in an educated society or not. Research at the national level shows that average happiness is considerably higher in nations where illiteracy is low and school enrolment high ( $\mathrm{N}$ 4.7.1). Happiness is also higher in countries where the citizens read newspapers and are connected to the Internet ( $\mathrm{N}$ 4.7.2). This is partly due to the fact that the modern economy requires an educated labour-force, but much of the difference remains when economic development is controlled. Probably, the good education of citizens also adds to happiness indirectly, among other things through its effects on democracy and tolerance.

These data place Confucianism in the right and Taoism partly right. Although higher education is not required for personal happiness, high-average education does add to the happiness of all. Classic Buddhist advice to renounce a school education is clearly not conducive to happiness in modern society. 


\section{Discussion}

So much for these reality tests of advice for a good life. Now some words about the limitations of this examination.

The reader should be aware that these tests deal with ancient Chinese versions of the philosophies. Modern versions of these philosophies may be more apt in modern society, for instance the present day version of Tibetan Buddhism as advocated by the Dalai Lama (Dalai Lama \& Cutler, 2000). Although there is of course a common core in each of these philosophies, the derived admonitions vary too much across time and place to allow generalization. In fact, each variant must be examined separately. This may be difficult to buy for believers who see only truth in these philosophical traditions.

Another thing to keep in mind is that this analysis is based on writings. Possibly practice differed somewhat from the theory presented in books. Statements of principles are typically more radical than choices made in real life and stated principle is sometime even contrary to actual life. This may be particularly true for the statements about retreat from worldly life made in classic Buddhism. Monastic life is still an earthly life and in this context it is worth remembering that cloisters used to own a lot of land and that monks often lived better than most peasants, many of whom would have been tied to the land as serfs.

Further we should not forget that these admonitions might have been more apt for the public to which they were addressed in the context of the society of their time. Confucianist advice was probably quite appropriate for the nobility of that time, that had an interest in maintaining the social order and that could profit from social engagement. Buddhist advice to forego earthly happiness was less fitted for this advantaged class, but might have provided solace for the mass of poor peasants. Buddhism may be more apt in an agrarian society, since human society seems to have been least livable in this phase of social evolution (Maryanski \& Turner, 1992; Sanderson, 1995, Chap. 8). In this context it was probably comforting to hear that enjoyment of life is neither possible nor desirable and that retreat from reality may help one to bear the miseries of life.

A last thing to remember is that the empirical tests performed here considered only aptness for the average citizen. It is quite possible that some of the recommendations work out differently for different people. For instance, the advice to avoid intimate involvements may be more appropriate for neurotic people than for those who are sociable. Future research should chart such contingencies. The data on conditions for happiness used here stem mainly from western nations. Possibly things work out differently in today's China or on the south-east Asian home ground of Buddhism. Time will tell.

Irrespective of these technical limitations there will be reservations about the approach followed here. This examination of reality consequences of life-philosophies may be as blasphemy for the devotee; and many philosophers will abhor great ideas being put to a consumer test.

Still we feel that this kind of research is badly needed. Recommendation meant to guide real life should be put to reality tests when possible, so that a body of evidence-based advice can develop. In health care we do not accept quack medicine anymore, and systematically investigate the effects of treatments. The time has come to do the same in counselling, including philosophical counselling. 
This kind of research will probably detract from the myth of timeless wisdom in such philosophies. Yet it does not necessarily shatter true conviction. When informed about the reality consequences of philosophies, people can make a more informed choice of views on life. It is better to opt for ancient Buddhism while acknowledging that this will not make for a happier life, than embracing the creed on the basis of a false illusion.

\section{Conclusion}

Classic Confucianist advice appears to be the most apt for finding happiness in present day society, in particular because of its recommendation that one become involved in real life. Classic Taoist advice is second best, its strong point is that it advises against too much social conformism and bookishness. Classic Buddhist advice is better avoided in modern society. Although it may provide some consolation for the chronically unhappy, the medicine seems to be worse than the disease.

Alongside this advice for individuals, Confucianist philosophy also gives sound advice with respect to societal conditions for happiness. Taoism and Buddhism add little to the idea of a good society, since they reject society altogether.

\section{References}

Bradburn, N. M. (1969). The structure of psychological wellbeing. Chicago: Aldine Publishing.

Brinkerhoff, M. B., \& Jacob, J. (1986). Quality of Life in an alternative lifestyle: The smallholding movement. Social Indicators Research, 18, 153-173.

Chan, W.-T. (1969). A source book in Chinese philosophy (translations). Princeton: Princeton University Press.

Chichao, L. (2000). History of Chinese political thought: During the early Tsin period. London: Routledge.

Dalai Lama \& Cutler, H.C. (2000). The art of happiness: A handbook for living. Sydney, Australia: Hodder Headline.

Fordyce, M. W. (1972). Happiness, its daily variation and relation to values. Dissertation US International University, San Diego.

Fung, Y.-L. (1985). Short history of Chinese philosophy. New York: The Free Press.

Goodhart, D. E. (1985). Some psychological effects associated with positive and negative thinking about stress event outcomes: Was Pollyanna right? Journal of Personality and Social Psychology, $48,216-232$.

Guoqing, Z. (2001a). Blue emotion. Taibei: Shenjing Press.

Guoqing, Z. (2001b). Mathematics of happiness shanghai. Shanghai: Sanlian Publishing Co.

Kircaldy, B., Furnham, A., \& Veenhoven, R. (2005) Health care and subjective well being in nations. In: A.-S. G. Antoniou, \& C. L. Cooper (Eds.), Research companion to organizational health psychology Cheltenham: Edgar Elgar Publishers.

Legge, J. (1971). Translation of confucian analects. New York: Dover Publications.

Legge, J. (1947). Translation of the works of Mencius. In The four books. Shanghai: The International Publication Society.

Lin, Y. (1949). The wisdom of China. London: Josoph.

Maryanski, A., \& Turner, J. H. (1992). The social cage: Human nature and the evolution of society. Stanford: Stanford University Press.

Sanderson, S. K. (1995). Social transformations. Oxford: Blackwell.

Sears, P. S., \& Barbee, A. H. (1977). Career and life-satisfaction among Terman gifted women. In J. C. Stanley, \& W. C. George (Eds.), The gifted and the creative Baltimore: John Hopkins University Press. 
Stutzer, A., \& Frey, B. (2003) Does marriage make happy or do happy people get married? Working paper, Institute for Empirical Research in Economics, Zurich University.

Veenhoven, R. (1984). Conditions of happiness. Dordrecht: Kluwer Academic.

Veenhoven, R. (1994). How satisfying is rural life? Fact and value. In J. Cecora (Ed.), Changing values and attitudes in family households, Implications for institutional transition in East and West. Bonn: Society for Agricultural Policy Research and Rural Sociology (FAA report 296).

Veenhoven, R. (1999). Quality-of-life in individualistic society: A comparison in 43 nations in the early 1990s. Social Indicators Research, 48, 157-186.

Veenhoven, R. (2003). Hedonism and happiness. Journal of Happiness Studies, 4, 437-457.

Veenhoven, R (2005). World database of happiness: Continuous register of research on subjective appreciation of life. Website at Erasmus University Rotterdam, http://worlddatabaseofhappiness.eur.nl. 